\title{
Dynamic bacterial and viral response to an algal bloom at subzero temperatures
}

\author{
Patricia L. Yager \\ University of Georgia \\ Tara L. Connelly \\ Behzad Mortazavi \\ K. Eric Wommack \\ Nasreen Bano
}

See next page for additional authors

Follow this and additional works at: https://scholarworks.wm.edu/vimsarticles

Part of the Environmental Sciences Commons

\section{Recommended Citation}

Yager, Patricia L.; Connelly, Tara L.; Mortazavi, Behzad; Wommack, K. Eric; Bano, Nasreen; Bauer, James E.; Opsahl, Stephen; and Hollibaugh, James T., Dynamic bacterial and viral response to an algal bloom at subzero temperatures (2001). Limnology and Oceanography, 46(4), 790-801.

https://doi.org/10.4319/lo.2001.46.4.0790

This Article is brought to you for free and open access by the Virginia Institute of Marine Science at W\&M ScholarWorks. It has been accepted for inclusion in VIMS Articles by an authorized administrator of W\&M ScholarWorks. For more information, please contact scholarworks@wm.edu. 


\section{Authors}

Patricia L. Yager, Tara L. Connelly, Behzad Mortazavi, K. Eric Wommack, Nasreen Bano, James E. Bauer, Stephen Opsahl, and James T. Hollibaugh 
Limnol. Oceanogr., 46(4), 2001, 790-801

(C) 2001, by the American Society of Limnology and Oceanography, Inc.

\title{
Dynamic bacterial and viral response to an algal bloom at subzero temperatures
}

Patricia L. Yager ${ }^{1}$

University of Georgia, School of Marine Programs, Athens, Georgia 30602-3636

Tara L. Connelly and Behzad Mortazavi

Florida State University, Department of Oceanography, Tallahassee, Florida 32306

K. Eric Wommack

University of Delaware, Delaware Biotechnology Institute, Newark, Delaware 19711

Nasreen Bano

University of Georgia, School of Marine Programs, Athens, Georgia 30602-3636

James E. Bauer

School of Marine Science, College of William and Mary, Gloucester Point, Virginia 23062

\section{Stephen Opsahl}

Joseph W. Jones Ecological Research Center, Route 2, Box 2324, Newton, Georgia 31770

James T. Hollibaugh

University of Georgia, School of Marine Programs, Athens, Georgia 30602-3636

\begin{abstract}
New evidence suggests that cold-loving (psychrophilic) bacteria may be a dynamic component of the episodic bloom events of high-latitude ecosystems. Here we report the results of an unusually early springtime study of pelagic microbial activity in the coastal Alaskan Arctic. Heterotrophic bacterioplankton clearly responded to an algal bloom by doubling cell size, increasing the fraction of actively respiring cells (up to an unprecedented $84 \%$ metabolically active using redox dye CTC), shifting substrate-uptake capabilities from kinetic parameters better adapted to lower substrate concentrations to those more suited for higher concentrations, and more than doubling cell abundance. Community composition (determined by polymerase chain reaction/DGGE and nucleotide sequence analysis) also shifted over the bloom. Results support, for the first time with modern molecular methods, previous culture-based observations of bacterial community succession during Arctic algal blooms and confirm that previously observed variability in pelagic microbial activity can be linked to changes in community structure. During early bloom stages, virioplankton and bacterial abundance were comparable, suggesting that mortality due to phage infection was low at that time. The virus-to-bacteria ratio (VBR) increased 10-fold at the height of the bloom, however, suggesting an increased potential for bacterioplankton mortality resulting from viral infection. The peak in VBR coincided with observed shifts in both microbial activity and community structure. These early-season data suggest that substrate and virioplankton interactions may control the active microbial carbon cycling of this region.
\end{abstract}

The role of heterotrophic bacteria in polar oceans has been debated since Sorokin first proposed microbial inhibition by

\footnotetext{
${ }^{1}$ Corresponding author (pyager@uga.edu).

\section{Acknowledgments}

We thank the U.S. Coast Guard, Captain J. M. Garrett, Science Liaison P. McGillivary, and the officers and crew of the USCGC Polar Sea for the opportunity to participate in the 1998 Science of Opportunity expedition; Chief Scientist L. Clough for excellent leadership and also for the use of her fluorometer at sea; J. Levitt and J. G. Harper for biovolume measurements; J. Cherrier for help with the TOC sampling; L. M. Proctor for providing the impetus and materials for the CTC measurements; R. L. Iverson for providing additional financial support for B.M.; and S. B. Joye and S. M. Holland for helpful comments on early drafts and figures.

This research was supported in part by Florida State University (research funds to P.L.Y.; a graduate teaching assistantship to T.L.C.), the National Science Foundation (grants OCE-9753170 and OCE-9896334 to P.L.Y.; OPP98-09971 to J.T.H.), and the National Research Council (to K.E.W.).
}

low temperature (see review by Karl 1993). Environmental scientists recently have become increasingly aware that extreme environments harbor unique, highly adapted microorganisms. Yet, despite the fact that cold-loving (psychrophilic) bacteria have been recognized for nearly $50 \mathrm{yr}$, the dominance and activities of these bacteria in perennially cold marine environments remain uncertain (Morita 1997).

A key question is whether the factors controlling bacterial activity in polar oceans differ substantially from those in temperate waters. Low temperature, interacting with available substrate concentration, may underlie seasonal cycles of marine bacterial activity at all latitudes and greatly influence organic carbon cycling in marine food webs (Pomeroy and Wiebe 1993; Shiah and Ducklow 1994), although studies of these effects in perennially cold oceans are rare. An enhanced threshold concentration for organic substrate at low temperature has been proposed on the basis of laboratory studies of temperate (mesophilic; Wiebe et al. 1993) and 
cold-tolerant (psychrotolerant) bacteria (Wiebe et al. 1992; Nedwell and Rutter 1994). Psychrophilic bacterial isolates reveal a more heterogeneous response to substrate, often showing less sensitivity to lower substrate concentrations at colder temperatures (Pomeroy pers. comm.). The outcome of competition between psychrophilic and psychrotolerant strains may depend on the combination of temperature and substrate concentration, although psychrophilic isolates outgrew psychrotolerant isolates at all substrate concentrations when temperature remained below $4^{\circ} \mathrm{C}$ (Harder and Veldkamp 1971). Although environmentally relevant variations in substrate sensitivity within these two thermal groups are not well known, one potentially unique feature of perennially cold oceans is the competitive interaction of these two groups of marine bacteria.

Field data comparing autotrophic with heterotrophic microbial activity further indicate that cold marine ecosystems may be unique. Uncoupling of primary production and bacterial production has been observed in some, although not all, polar regions (see review by Karl 1993). Polar pelagic bacterial biomass rarely reaches the levels predicted from observed chlorophyll $a$ inventories. However, bacterial growth rates measured in a variety of polar waters have been found to be similar to those in temperate zones (Rivkin et al. 1996; Rich et al. 1997; Ducklow et al. 1998). Explanations for this apparent inconsistency have focused on hydrography (i.e., the mix of psychrotolerant and psychrophilic strains present; Yager and Deming 1999), the transformation of particulate phytoplankton biomass to utilizable dissolved organic matter (DOM; Billen 1990; Azam et al. 1991; Carlson et al. 1998), bacterivory (Billen and Becquevort 1991; Putt et al. 1991), and mortality from viral infection and lysis (Steward et al. 1996). Because these mechanisms also contribute to variability in temperate marine microbial activity, perhaps the basic controls on the Arctic system are not so different from those in temperate systems. Because the greatest degree of uncoupling occurs during high $\mathrm{Chl} a$ concentrations (Karl 1993), algal blooms are the critical conditions for studying these issues.

Community structure can be the key to the variable microbial activities observed in temperate and polar marine ecosystems. In mesocosm incubations, marine bacterial community composition and ectoenzyme activity can change dramatically in response to short-term (1-2 d) changes during a phytoplankton bloom (e.g., Riemann et al. 2000). This same process may operate in Arctic seas. Succession of cultivable bacterial phenotypes was demonstrated in nearshore waters of the Beaufort Sea according to season and geography and in response to algal blooms (Kaneko et al. 1977, 1979). All isolated bacterial strains were either psychrophilic or psychrotolerant and tended to differ significantly from those found in other marine environments. Although conclusions drawn about in situ communities by use of phenotypic characteristics of cultivable bacteria are limited by the ability to obtain pure cultures, this observed potential for high genetic diversity was confirmed recently by molecular analyses of subsurface Central Arctic Ocean bacterial communities (Ferrari and Hollibaugh 1999).

In this study, we aimed to evaluate whether observed variations in low-temperature pelagic microbial activity (e.g.,

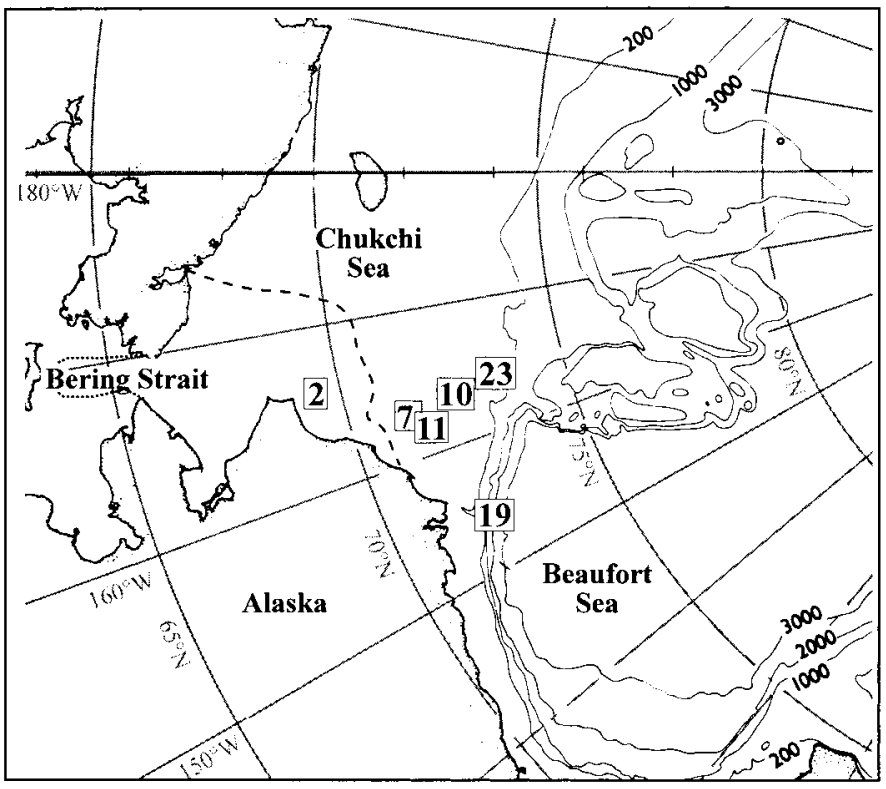

Fig. 1. Bathymetric map of the Chukchi Sea (adapted from Aagaard 1989), with sampling locations labeled with station numbers inside squares. Depth contours are in meters. The dotted line indicates the southern extent of sea ice near the beginning of expedition (2 June 98); the dashed line indicates the southern extent of sea ice near the end of the expedition (7 July 98).

Yager and Deming 1999) are linked to variability in microbial community structure. During a springtime study in coastal Alaska, we tracked an algal bloom by traveling north through the Chukchi Sea (Fig. 1). By combining a suite of microbial activity measurements with bacterial community structure indices, biogeochemical inventories, and virioplankton enumeration, we observed an apparent microbial community succession in both activity and composition. The data suggest a key role for virioplankton in both microbial community composition and carbon cycling in this high-latitude marine environment.

\section{Materials and methods}

Sample collection-Six stations were occupied during the U.S. Coast Guard icebreaker Science of Opportunity research expedition (AWS98; aboard USCGC Polar Sea; 1 June-7 July $\left.1998 ; 69-73^{\circ} \mathrm{N}, 154-166^{\circ} \mathrm{W}\right)$, along an approximately south-to-north transect across the Chukchi Sea (Fig. 1; Table 1). The southernmost station (Sta. 2) was sampled at the beginning of the expedition, midcruise stations (Sta. 7,10 , and 11) were sampled near the same location within $5 \mathrm{~d}$ of each other, and northernmost stations (Sta. 19 and 23) were sampled later in the expedition. Shipboard observations of ice cover, weather, and geographic location were collected continuously. A SeaBird CTD equipped with a rosette of 12 30-liter Niskin bottles was deployed at each station. Distributions of conductivity, temperature, and depth; nutrients $\left(\mathrm{NO}_{3}{ }^{-}, \mathrm{NO}_{2}{ }^{-}, \mathrm{NH}_{4}{ }^{+}\right.$, and $\left.\mathrm{PO}_{4}{ }^{3-}\right)$; $\mathrm{Chl} a$; total and particulate organic carbon and nitrogen (TOC, TON, POC, and PON); and bacterial abundance were obtained either from continuous profiles or from a minimum of six discrete depth sam- 


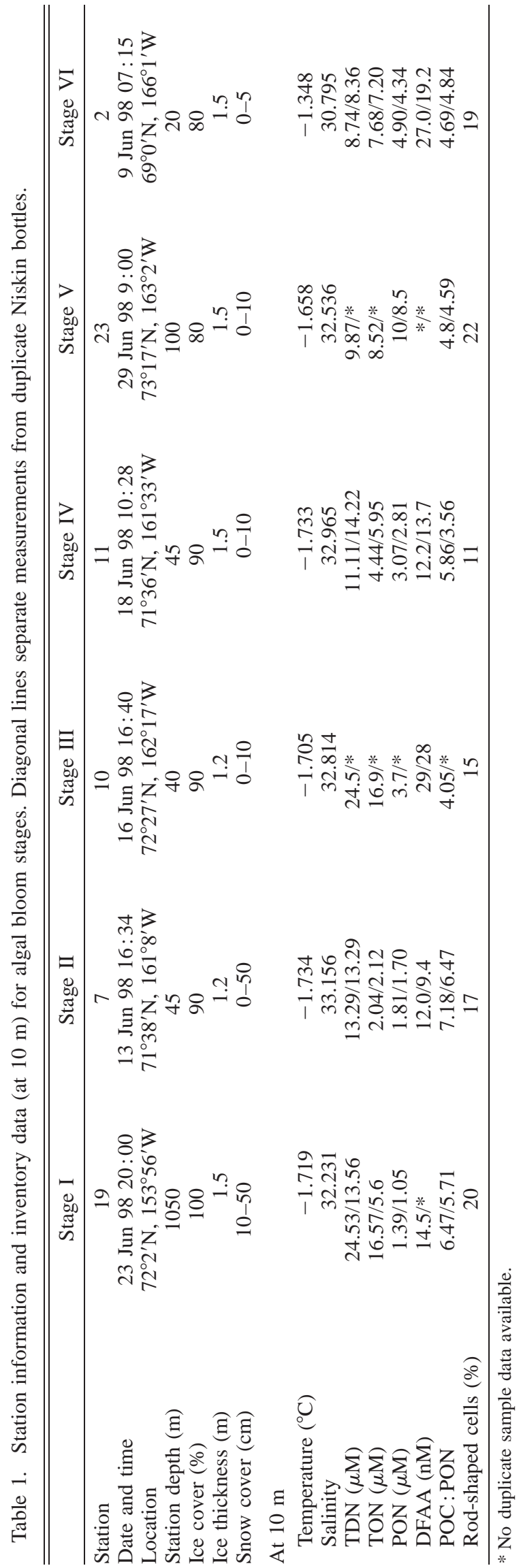

ples collected throughout the water column. We focused our attention on samples from a depth of $10 \mathrm{~m}$, typically just below the summertime surface meltwater lens but above the perennial pycnocline. At this depth, we also determined bacterial biovolume, the percentage of metabolically active (i.e., $\% \mathrm{CTC}+$ ) bacteria, viral abundance, dissolved free amino acid (DFAA) concentrations, bacterial community structure, and kinetic parameters for community uptake of amino acids at in situ temperatures. Four stations (Sta. 2, 7, 11, and 19) were "full" stations where all described variables were measured. Two (Sta. 10 and 23) were "short" stations, where only a subset of data was collected.

Confidence intervals for all inventory measurements (reported as $\pm 95 \%$ ) were calculated by estimating the shortterm SD (or repeatability) from the differences between duplicate measurements (Dickson and Goyet 1996). To incorporate small-scale heterogeneity, duplicates were collected from different Niskin bottles sampled at the same depth and station. Variability estimated in this way includes a measure of small-scale environmental patchiness; analytical precision assessed by repeated measures of the same sample was always greater.

Nutrients - Seawater samples were filtered through GF/F filters and frozen (at $-40^{\circ} \mathrm{C}$ ) for analysis at Florida State University. Nitrate plus nitrite (NOx) concentrations were determined with a chemiluminescence detector method (Braman and Hendrix 1989). Nitrite concentrations were measured colorimetrically (Strickland and Parsons 1972) on separate samples and subtracted from NOx to yield nitrate $\left(\mathrm{NO}_{3}{ }^{-}\right)$. Ammonium was determined with the salicylate-hypochlorite method (Bower and Holm-Hansen 1980). Soluble reactive phosphate (SRP) was determined by the ascorbic acid-phospho-molybdate method (Strickland and Parsons 1972).

Chl a-Generally, 1 liter of seawater was filtered through a $\mathrm{GF} / \mathrm{F}$ filter, and then the filters were stored briefly at $-40^{\circ} \mathrm{C}$. Pigments were extracted for $18-24 \mathrm{~h}$ in $90 \%$ acetone, and the chlorophyll concentrations were determined fluorometrically (Strickland and Parsons 1972) at sea with a Turner Fluorometer Model 112. The fluorometer was calibrated with a commercially available Chl $a$ standard (Sigma) that was dissolved in $90 \%$ acetone.

TOC/TON-Duplicate unfiltered seawater samples were collected according to the method of Knap et al. (1996). Samples were quick-frozen by use of an aluminum block chilled to $-40^{\circ} \mathrm{C}$, stored frozen, and processed ashore. TOC was measured after acidifying (with $25 \mu l$ of high-purity $\mathrm{HCl}) 4 \mathrm{ml}$ of sample and then sparging with ultra-high purity air for $5 \mathrm{~min}$ to remove dissolved inorganic carbon. Concentrations were measured on a Shimadzu TOC-5000A hightemperature catalytic oxidation system by use of a four-point calibration curve with glucose as a standard. High-purity distilled water blanks were run after every few samples to ensure that there was no carryover. The average coefficient of variation for duplicate TOC analyses on the same sample was $1.2 \%$. Total dissolved nitrogen (TDN) was measured by use of the alkaline persulfate oxidation method (Koroleff 
1983; Loh and Bauer 2000). TON was calculated by subtracting NOx from TDN.

$D F A A$ - The procedure for measuring DFAA was based on the high-pressure liquid chromatography (HPLC) technique of Lindroth and Mopper (1979). The amino acids quantified were aspartic acid, glutamic acid, serine, glycine, threonine, alanine, and tyrosine. Analytical variability based on duplicate analysis of the same sample was $<25 \%$.

POC/PON-Samples (1 liter) were collected according to the method of Knap et al. (1996) and processed at the UGA Chemical Analysis Facility with a Perkin-Elmer 240C CHN analyzer. Dissolved organic carbon (DOC) and nitrogen concentrations were computed by subtracting POC from TOC and PON from TON.

Bacterial abundance-The compound 4', 6-diamidino-2phenylindole (DAPI) was used to stain and enumerate total bacteria according to the method of Knap et al. (1996), except that duplicate subsamples from each station were fixed with $2 \%$ borate-buffered formalin and stored cold $\left(2^{\circ} \mathrm{C}\right)$ and dark until processed ashore within 2 weeks of our return.

Biovolume - Samples used to determine cell volume were prepared in the same manner as for bacterial abundance. Biovolume was measured manually according to the method of Yager and Deming (1999), except that cells were stained with DAPI and measurements were made on at least 300 cells from each duplicate sample. Application of our method to UV-fluorescent, 0.91- $\mu \mathrm{m}$ diameter microspheres (Polysciences), gave a mean diameter of $1.095 \mu \mathrm{m}( \pm 0.010 \mu \mathrm{m}$; $n=302$ ), with the oversizing presumably due to fluorescent halo effects. We therefore reduced cell dimensions by $17 \%$ to correct for this effect.

Active cells-The compound 5-cyano-2, 3-ditoyl tetrazolium chloride (CTC) was used to identify actively respiring bacteria (Sherr et al. 1999). Duplicate 1-ml subsamples were incubated $\left(3 \mathrm{~h},-1.5^{\circ} \mathrm{C}\right.$, dark) with $5-\mathrm{mM}$ (final concentration) CTC, fixed with $5 \%$ (final concentration) formalin, and frozen $\left(-40^{\circ} \mathrm{C}\right.$ shipboard, $-80^{\circ} \mathrm{C}$ ashore $)$ until processed (Sherr et al. 1999). Control samples were fixed and processed without the addition of CTC. Killed controls (incubating with CTC after fixation) routinely indicate $<1 \%$ activity. At Sta. 11 and 19, 1 liter of seawater was gravity filtered directly from the Niskin through a baked, rinsed, 293-mm glass-fiber filter (Gelman A/E; nominal $1 \mu \mathrm{m}$ pore size). Filtered seawater was processed as described above to compare "free-living" bacteria with the entire (unfiltered) population.

Uptake kinetics-Substrate uptake kinetic parameters and incorporation efficiencies were determined from incorporation and respiration of ${ }^{14} \mathrm{C}$-labeled mixed amino acids, measured according to the method of Yager and Deming (1999) as a function of increasing substrate concentration at in situ temperatures. Time-course experiments (duplicate incubations; four time points) were run at all substrate concentrations to determine total utilization rate at each station and to confirm the time period (typically $\sim 8 \mathrm{~h}$ ) over which rates were linear and incorporation efficiencies stabilized. Kinetic parameters (specific affinity and maximum utilization rate), estimated by nonlinear curve fits to the hyperbolic Michaelis-Menton equation, are considered community averages (see discussion in Yager and Deming 1999).

Microbial community structure-Seawater (6-9 L) was filtered through a $0.22-\mu \mathrm{m}$ Sterivex filter cartridge (Millipore). DNA was extracted, amplified, and analyzed by use of the methods described by Ferrari and Hollibaugh (1999) and Bano and Hollibaugh (2000). A 16S rRNA gene fragment was amplified by polymerase chain reaction (PCR) with use of a fluorescein-labeled universal primer $517 \mathrm{r}$ (complementary to positions 517-533 in the Escherichia coli $16 \mathrm{~s}$ rRNA gene; Brosius et al. 1978) and a bacterial primer $356 \mathrm{f}$ (complementary to E. coli positions 340-356; Myers et al 1985 ) with a 40-bp GC clamp. PCR product was analyzed by DGGE with use of a CBS Scientific DGGE system. For each sample, $500 \mathrm{ng}$ of PCR product was loaded on a $6.5 \%$ polyacrylamide gel with a $45 \%-65 \%$ gradient. Bands of interest were excised from the gel, and DNA was eluted (by incubating in $50 \mu \mathrm{L}$ water at $60^{\circ} \mathrm{C}$ for $2 \mathrm{~h}$ ) and sequenced by use of the automated sequencer at the University of Georgia Molecular Genetics Instrument Facility (MGIF) with 356f, 517r, or both primers. DGGE gel images were analyzed by use of Molecular Analyst Fingerprint Plus software (Bio-Rad). DGGE banding patterns were compared by use of similarity dendrograms.

Clone libraries were constructed from four samples (Sta. $2,7,11$, and 19). The $16 \mathrm{~S}$ rDNA of each sample was amplified in triplicate by use of the universal eubacterial $16 \mathrm{~S}$ rRNA primers 9F (complementary to E. coli positions 927 ) and $1525 \mathrm{R}$ (complementary to E. coli positions $1525-$ 1542). PCR product was cloned by use of the PGEM-T Easy Vector (Promega) cloning kit. Twenty colonies from each clone library were chosen, and DGGE profiles of reamplified cloned DNA were used to identify the corresponding band in the DGGE fingerprint of the original sample. We sequenced 1-2 clones representing each band and assumed that other bands with identical migration have the similar sequence (Riemann et al. 2000). To obtain full-length sequences of the inserts, plasmid primers Sp6 and T7 and internal primer $356 f$ were used. All sequences obtained from an automatic sequencer (MGIF) were edited by use of the Genetics Computer Group package (Wisconsin Package). Sequences were confirmed by use of the Ribosomal Database Project's CHIMERA-CHECK program. The closest relatives of sequences were found with use of an alignment algorithm (BLAST; Altschul et al. 1990). Sequences have been submitted to GenBank under accession numbers AF327027AF327036.

Viral abundance-Counts of virus-like particles (VLPs) were measured with epifluorescence microscopy and the dsDNA-binding fluorochrome SYBR Gold (Molecular Probes) according to the method of Chen et al. (2001). Total counts were scaled to bacterial counts from each individual sample to give a virus-to-bacteria ratio (VBR). Perhaps because samples for virus counts were stored $>1$ month longer 


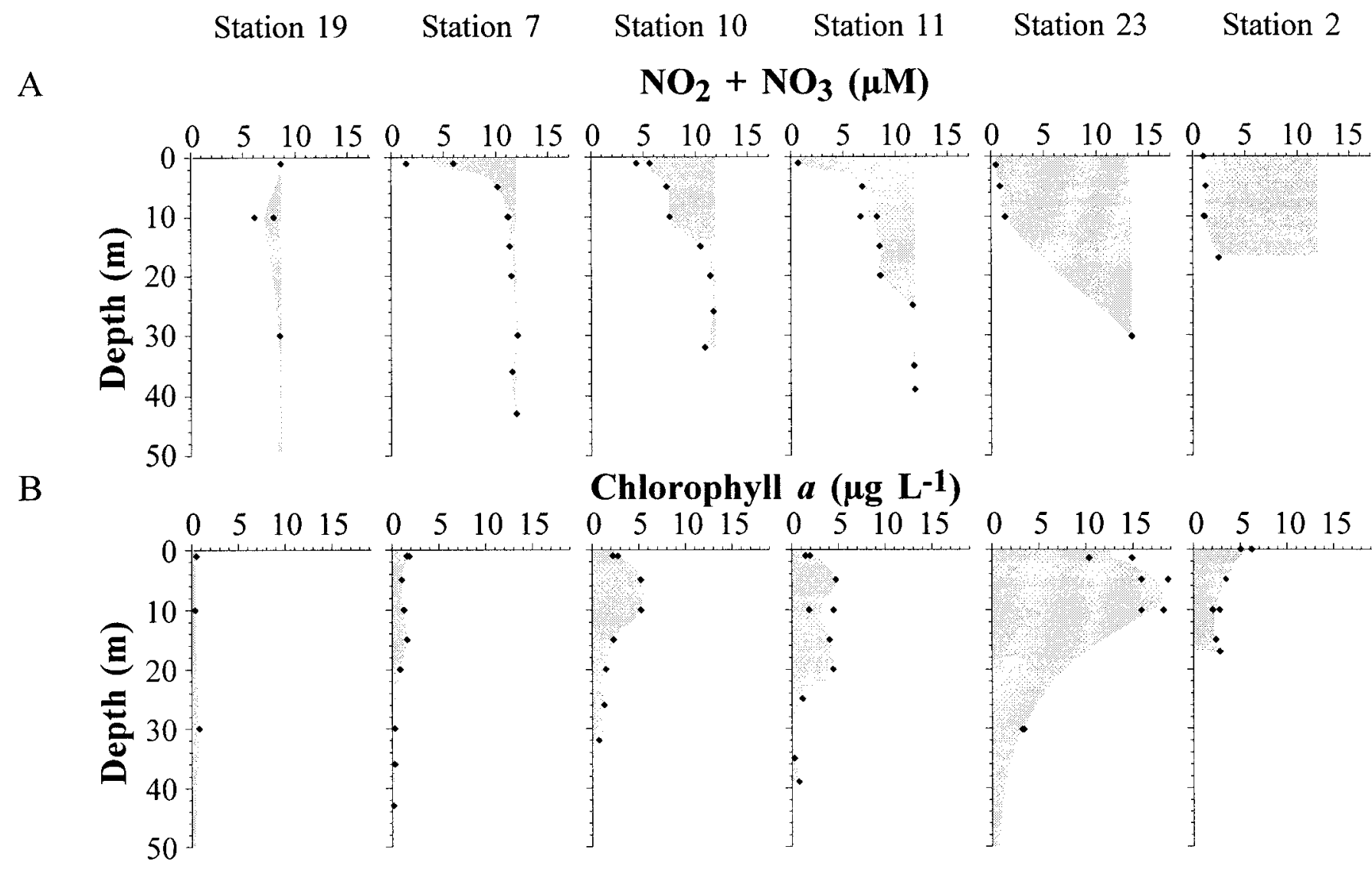

\section{Stage I Stage II Stage III Stage IV Stage V Stage VI}

Fig. 2. Depth profiles of (A) NOx $(\mu \mathrm{M})$ and (B) Chl $a\left(\mu \mathrm{g} \mathrm{L}^{-1}\right)$ concentrations, arranged according to algal bloom stage designated in Table 1. The shaded gray area indicates the estimated seasonal nutrient depletion (A) or Chl $a$ buildup (B).

than those used for bacterial abundance (e.g., Turley and Hughes 1992), the total number of bacteria counted by use of SYBR Gold was about a factor of two less than those in counts made immediately after the cruise by use of DAPI. Assuming that viral DNA degraded at the same rate as bacterial DNA, we multiplied measured VBR by total bacterial abundance (measured with DAPI) to estimate total viral abundance.

Results

Field conditions-All stations had $\geq 80 \%$ ice cover, $1-2$ $\mathrm{m}$ ice thickness, and 0-50 cm snow thickness at the time of sampling (Table 1). Seawater temperatures ranged from -1.8 to $-1.3^{\circ} \mathrm{C}$, and salinity ranged from 28.9 to 33.6 (PSS) in the upper $50 \mathrm{~m}$ of the water column. Most observed algal biomass appeared to be associated with the sea ice. Extensive blooms of the colonial subice diatom, Melosira arctica, dominated biomass, but algal composition data (von Quillfeldt pers. comm.) suggest that water column species were also present.
Nutrients, Chl a, and organic matter inventories-NOx concentrations (Fig. 2 ; $\pm 1.1 \mu \mathrm{M}$ ) ranged from relatively depleted $(<2.5 \mu \mathrm{M})$ throughout the water column (southernmost Sta. 2) to uniformly high $(>6 \mu \mathrm{M}$; northeasternmost Sta. 19). Midcruise stations exhibited near-surface depletions in NOx that deepened between Sta. 7 and 11. Nitrite concentrations were always $<0.1 \mu \mathrm{M}$, so NOx profiles were dominated by changes in $\mathrm{NO}_{3}^{-}$concentration. Ammonium concentrations measured $>2 \mu \mathrm{M}$ at all depths and stations, so we infer that samples were contaminated and do not report the data. SRP ranged from 0.9 to $1.7( \pm 0.26) \mu \mathrm{M}$ (data not shown), with lower concentrations typically near the surface.

Chl a concentrations ( $\pm 0.63 \mu \mathrm{g} \mathrm{L}^{-1}$; Fig. 2) were high (up to $6 \mu \mathrm{g} \mathrm{L}^{-1}$ ) throughout the water column at the southernmost station (Sta. 2) and were uniformly low $\left(<1 \mu \mathrm{g} \mathrm{L}^{-1}\right)$ at the northeasternmost station (Sta. 19). Sta. 11 exhibited greater near-surface and mid-water column Chl $a$ concentrations (up to $5 \mu \mathrm{g} \mathrm{L}^{-1}$ ) than those sampled near the same location 5 days earlier (Sta. 7; up to $2 \mu \mathrm{g} \mathrm{L}^{-1}$ ). The highest Chl $a$ values of the cruise (up to $19 \mu \mathrm{g} \mathrm{L}^{-1}$ ) were measured at the northwesternmost station, Sta. 23. 


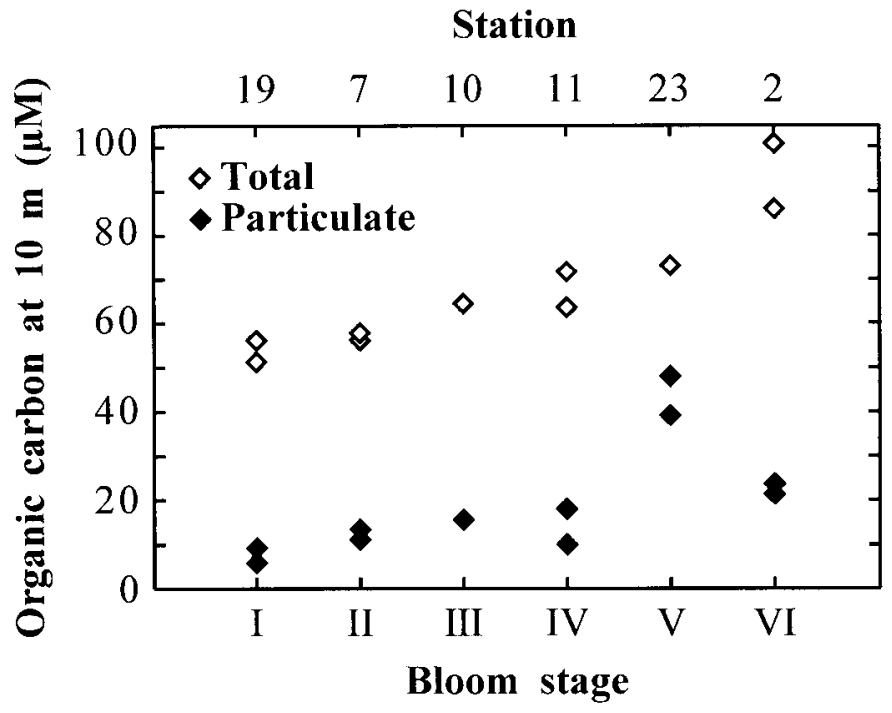

Fig. 3. TOC and POC concentrations $(\mu \mathrm{M})$ at $10 \mathrm{~m}$ depth, arranged according to algal bloom stage. DOC concentrations are estimated by difference.

Using NOx and Chl $a$ profiles (Fig. 2), we arranged stations into a hypothesized bloom progression (Table 1; see Sambrotto et al. 1986), with the northeastern station (Sta. 19) designated as Stage I (uniformly low Chl $a$ and high NOx), temporally sequential midpoint stations (Sta. 7, 10, and 11) as Stages II, III, and IV, respectively, the high-Chl $a$, low-NOx station (Sta. 23) as Stage V, and the southernmost station (Sta. 2; uniformly low NOx and moderate Chl a) as Stage VI. Arranging the stations in this way is consistent with the progression of a light-limited springtime algal bloom (moving from south to north with the season) starting near the surface (beneath the ice, as the snow cover started to thin) and then tending to deepen into the water column through each stage. All other results will be presented within the framework of this bloom progression.

TOC concentrations (at $10-\mathrm{m}$ depth) increased significantly (Fig. 3) from Stage I (51-56 $\mu \mathrm{M})$ to Stage VI (86$101 \mu \mathrm{M})$. This increase was dominated by increases in POC during Stages II to $\mathrm{V}$ and then by an increase in DOC at Stage VI (Fig. 3). TON concentrations were generally low $(<10 \mu \mathrm{M}$; Table 1$)$ and tended to be dominated by the particulate pool. The $\mathrm{C}: \mathrm{N}$ of particulate organic matter (POM) averaged $6.5( \pm 0.6 ; n=4)$ in early stages (I and II) and $4.6( \pm 1.0 ; n=7)$ during later stages (III-VI; Table 1). The $95 \%$ confidence intervals were $\pm 10 \mu \mathrm{M}$ for TOC, $\pm 6.4 \mu \mathrm{M}$ for TDN, $\pm 5 \mu \mathrm{M}$ for POC, and $\pm 0.7 \mu \mathrm{M}$ for PON. DFAA concentrations were very low (12-29 $\pm 8.5 \mathrm{nM})$ and showed little variation over the bloom stages (Table 1). Ammonium concentrations, measured by HPLC, were consistently low $(<1 \mu \mathrm{M}$; data not shown).

Bacterial abundance, biovolume, and percentage activeBacterial abundance (at 10-m depth; Fig. 4) across the six stations ranged from 0.20 to $0.94( \pm 0.08) \times 10^{9} \mathrm{~L}^{-1}$, with the highest abundance occurring at the southernmost station (Sta. 2, Stage VI). The percentage of CTC + cells at $10 \mathrm{~m}$ ranged from $8.8 \%$ to $84 \%$ ( $\pm 5.8 \%$ ), with the highest percent

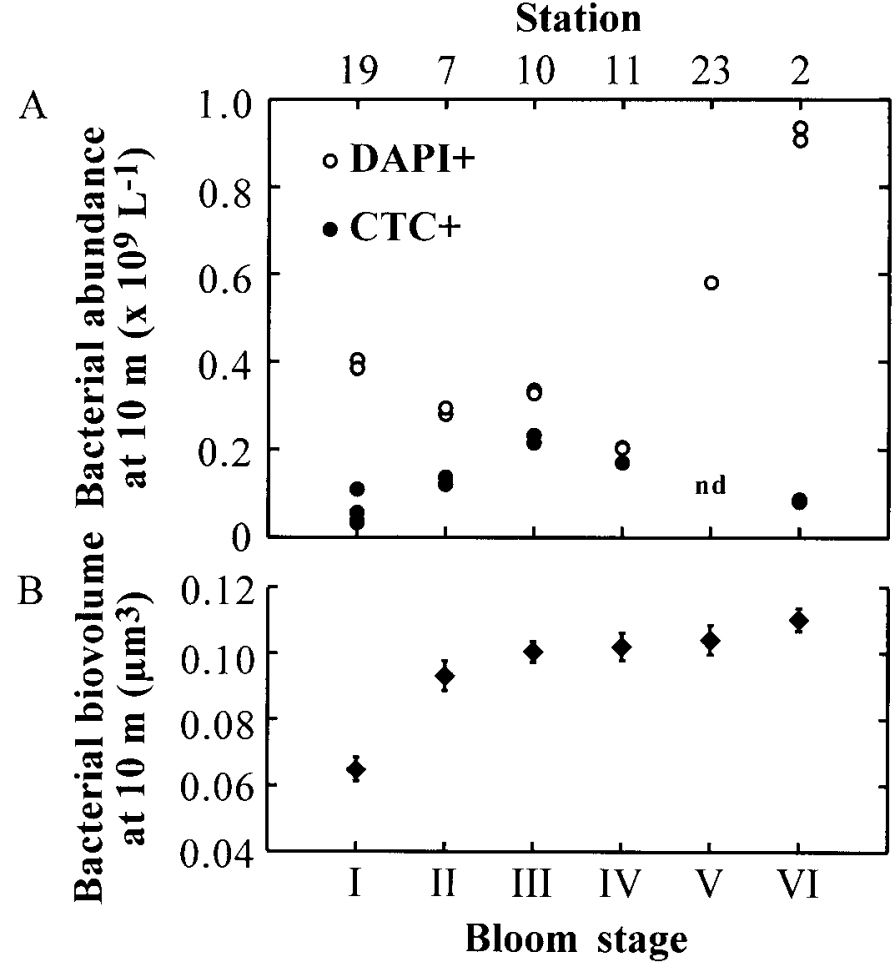

Fig. 4. Bacterial measurements arranged according to the algal bloom stage: (A) total bacterial abundance (DAPI+) at 10-m depth $\left(10^{9} \mathrm{~L}^{-1}\right)$ and the number of metabolically active $(\mathrm{CTC}+)$ cells $\left(10^{9}\right.$ $\mathrm{L}^{-1}$; nd = no CTC data for Stage V); (B) bacterial biovolume $\left(\mu \mathrm{m}^{3}\right)$ as a function of bloom stage, with error bars indicating the $95 \%$ confidence interval $(n=300)$.

active observed at midpoint Sta. 11 (Stage IV). Bacterial biovolume (Fig. 4) ranged from 0.065 to 0.110 ( \pm 0.006$)$ $\mu \mathrm{m}^{3}$ per cell, with the largest cells found at the southernmost station (Sta. 2, Stage VI). The percentage of rod-shaped cells ranged from $11 \%$ to $22 \%$, with the fewest rods found at Sta. 11 (Table 1). Significant increases (Fig. 4) in number of $\mathrm{CTC}+$ cells and cell volume were observed between Stages I-IV, yet total bacterial abundance did not increase significantly until Stages V and VI. The percentage of respiring cells $(82 \%-84 \%)$ measured at Stage IV is among the highest values ever measured with use of the CTC technique. Sta. 10 also exhibited very high CTC activity (64\%-71\%). These high values are supported by low blanks (negligible red autofluorescence) on control samples, a wide range of observed activity on samples treated and stored identically, and the similarity of total bacterial abundances measured on CTC samples (data not shown) to those measured with the standard technique described above.

At Sta. 19 (Stage I), filtered seawater samples contained $77 \%$ of the bacterial abundance in whole-water samples but only $35 \%$ of the CTC + activity (Table 2). At Sta. 11 (Stage IV), filtered samples accounted for nearly the same fraction of whole-water biomass as before but contained no detectable CTC + activity (Table 2). Thus, the relative fraction of active cells associated with particles increased from Stage I $(65 \%)$ to Stage IV (100\%). 
Table 2. Whole community versus free-living biomass and activity.

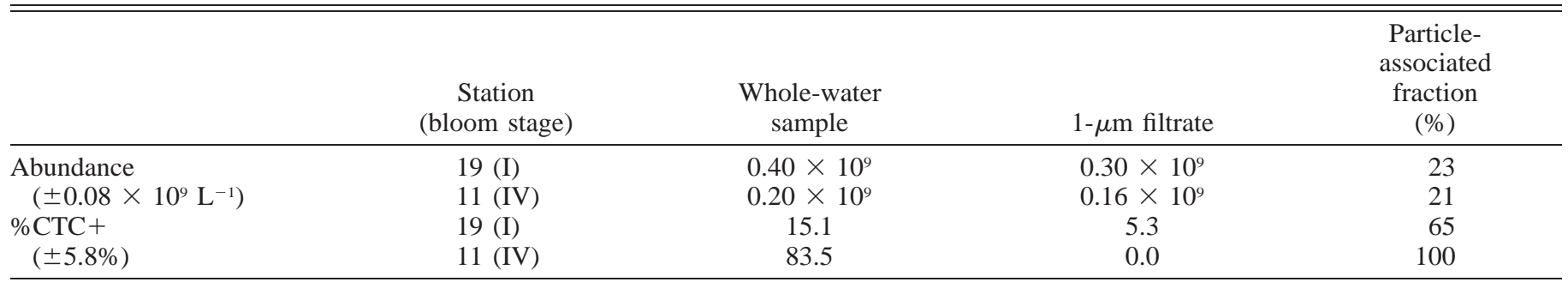

Uptake kinetics - Specific affinities for amino acids (Fig. 5) ranged from $48.7( \pm 3.3 ; n=6)$ to $57.9( \pm 4.7 ; n=6)$ $\mathrm{pL}$ cell ${ }^{-1} \mathrm{~h}^{-1}$ and were comparable to those measured for bacterial isolates considered well adapted to low-nutrient conditions (see discussion in Yager and Deming 1999). Maximum specific utilization rates $\left(V_{\max }\right.$; Fig. 5) ranged from $1.15( \pm 0.04 ; n=6)$ to $2.17( \pm 0.15 ; n=6) \mathrm{amol} \mathrm{cell}^{-1} \mathrm{~h}^{-1}$. These estimates of community utilization of mixed amino acids shifted from a signature typical of oligotrophs (e.g., high specific affinity and low $V_{\max }$ ) in Stages I and II to kinetic parameters more typical of bacteria accustomed to higher concentrations of substrate (e.g., lower specific affinity and higher specific $V_{\max }$ ) during Stages IV and VI when DOC increased (Fig. 5). To our knowledge, this is the first time such a shift has been observed in the field. The incorporation efficiency of amino acids at in situ temperature was $80 \%-85 \%$ for the 1-nM addition and decreased with increasing substrate concentration (data not shown).

Microbial community structure-Changes in the DGGE banding pattern occurred stepwise through different stages of the algal bloom (Fig. 6). One common DGGE band, designated as Band A, was found throughout the water column during Stage I (other depth data not shown), disappeared at $10 \mathrm{~m}$ (and other shallow depths) during Stage IV and V, and then reappeared during Stage VI. The two clones (AWS9819a and AWS98-2a) containing sequences that migrated to the same position as Band A in PCR/DGGE (as well as the

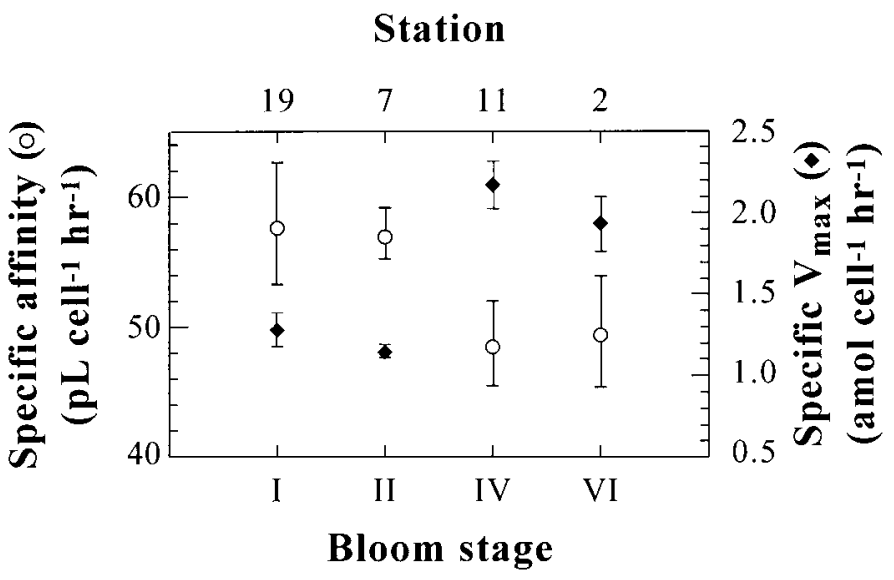

Fig. 5. Cell-specific kinetic parameters for amino acid utilization arranged according to bloom stage. Open circles are specific affinity $\left(\mathrm{pL}\right.$ cell ${ }^{-1} \mathrm{hr}^{-1}$ ); filled diamonds are specific $V_{\max }$ (amol cell $\left.{ }^{-1} \mathrm{~h}^{-1}\right)$. Error bars indicate $95 \%$ confidence limits.

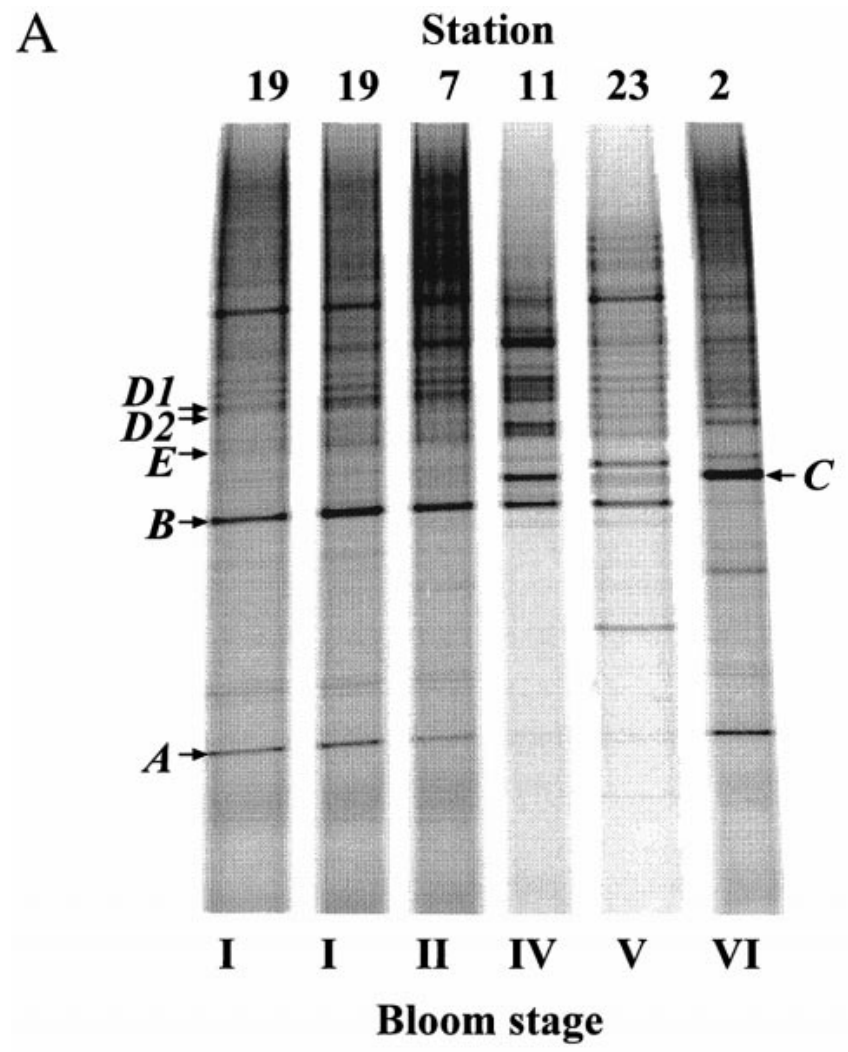

B

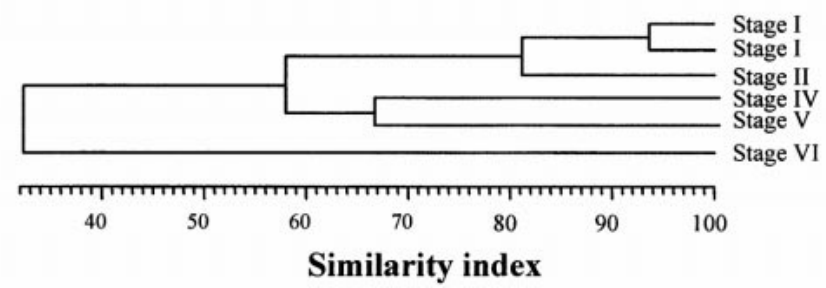

Fig. 6. (A) Negative image of a DGGE gel of AWS98 samples. Samples are arranged according to bloom stages. Stage I shows good replication from duplicate samples collected from separate Niskin bottles at the same depth and station. No data for Stage III. Bold italic letters (A, B, C, D, and E) indicate excised and sequenced bands. (B) Dendrogram of DGGE band pattern similarity. 
Table 3. Similarity of AWS98 clone sequences to GenBank sequences, as determined by BLAST.

\begin{tabular}{|c|c|c|c|c|}
\hline Clone & $\begin{array}{l}\text { Sequence } \\
\text { length }\end{array}$ & $\begin{array}{c}\text { Closest matching } \\
\text { organisms }\end{array}$ & $\begin{array}{c}\text { Accession number } \\
\text { of closest } \\
\text { matches (\% } \\
\text { similarity) }\end{array}$ & $\begin{array}{c}\text { DGGE } \\
\text { band }\end{array}$ \\
\hline \multirow[t]{3}{*}{ AWS98-2a } & 715 & $\alpha$-Proteobacterium (clone $\mathrm{NaC} 1-3$ ) & AF2U5616 (99) & $\mathrm{B}$ \\
\hline & & $\alpha$-Proteobacterium (clone PLY43) & U13159 (99) & \\
\hline & & $\alpha$-Proteobacterium (clone SAR407) & U75253 (98) & \\
\hline AWS98-19b & & S. pseudocostatum chloroplast & X82155 (95) & \\
\hline \multirow[t]{3}{*}{ AWS98-11b } & 726 & Cyanobacterium (clone LD27) & AJ007876 (98) & $\mathrm{B}$ \\
\hline & & Diatom chloroplast (clone OCS54) & AF001657 (97) & \\
\hline & & S. pseudocostatum chloroplast & X82155 (97) & \\
\hline AWS98-11c & 481 & S. pseudocostatum chloroplast & X82155 (99) & $\mathrm{C}$ \\
\hline AWS98-2c & 696 & S. pseudocostatum chloroplast & X82155 (99) & $\mathrm{C}$ \\
\hline
\end{tabular}

shorter 120-bp sequence eluted from Sta. 19 Band A) were $>98 \%$ similar to $\alpha$-Proteobacteria clones (NAC1-3, PLY43, and SAR407; Table 3; Fig. 7) located within the SAR 11 cluster. DGGE bands designated as Bands B and C (Fig. 6) represent the algal component of the community that was not removed from our sample (since we did not screen the sample to remove phytoplankton and chloroplast DNA can be amplified by use of the $356 \mathrm{f} / 517 \mathrm{r}$ primer pair). Band $\mathrm{B}$ was found at all stations except Sta. 2. BLAST analyses of the two clones (AWS98-19b and AWS98-11b) containing sequences that migrated to the same position as Band B matched $(97 \%)$ with an unidentified Cyanobacterium (clone LD27; Table 3; Fig. 7). The next three closest matches, however, were diatom chloroplasts (Table 3; Fig. 7). Because cyanobacteria have not been reported in polar marine waters, the Band B sequence is most likely from a diatom chloroplast. Band C was present in Stage IV and VI (Fig. 6). Clones (AWS98-11c and AWS98-2c) containing sequences that migrated to the same band position were also related to diatom chloroplasts (Table 3; Fig. 7). Bands D1 and D2 had very similar melting points in DGGE and cloned sequences migrating to the same position are related to a Cytophaga species. Although D1 appears to occur at all stages (Fig. 6), D2 appears during Stage IV. Clone AWS98-11d from Stage IV was 99\% similar to a Cytophaga strain (JTB244; Table 3; Fig. 7). Clones AWS98-19d and AWS98-7d were 99.7\% similar to each other but only $95 \%$ similar to clone AWS9811d and to the same (JTB244) Cytophaga strain (Table 3; Fig. 7). Band E was observed in all stages but was most prominent in Stage IV (Fig. 6). A sequence with the same melting point, from clone AWS98-7e, was 94\% similar to a $\gamma$-Proteobacterium strain (OM241; Table 3; Fig. 7).

Virioplankton abundance-VLP abundance (Fig. 8A) was always greater than bacterial abundance, was low $\left(<1 \times 10^{9}\right.$ $\mathrm{L}^{-1}$ ) during early stages of the bloom, and increased more than fourfold during peak bloom. During Stages I and II,
VLP abundance was of the same order of magnitude as bacterial abundance (VBR 1; Fig. 8). VBR increased dramatically (up to $\sim 20$ ) during Stages III and IV (Fig. 8) and then decreased somewhat during later stages. The peak in VBR coincides with a small decrease in bacterial abundance (Fig. 3), as well as with major shifts in kinetic parameters (Fig. 5) and community structure (Fig. 6). The 95\% confidence interval for VBR was \pm 3.4 , a high value caused by sample patchiness during peak bloom stages (Fig. 8).

\section{Discussion}

Recent investigations of microbial activity in the Alaskan Arctic have tended to occur in the late summer, when surface nitrate inventories are $<1 \mu \mathrm{M}$ and DOM and DFAA concentrations are high (up to $80 \mu \mathrm{M}$ and $250 \mathrm{nM}$, respectively; Rich et al. 1997; Wheeler et al. 1997). Perhaps because of relatively high concentrations of labile DOM at this time of year, community respiration typically exceeds primary production, heterotrophic bacteria actively cycle labile DOM, and bacterial biomass is high (Cota et al. 1996; Rich et al. 1997; Sherr et al. 1997), despite in situ temperatures remaining low and both bacterivory and viral mortality having a significant impact on bacterial production (Steward et al. 1996; Sherr et al. 1997).

Estimates of substrate concentrations available to the bacteria during our early-season expedition, however, suggest a different ecosystem. Ice algal biomass and POM dominated the observed spring bloom production; sources and sinks of DOM were either negligible or balanced until very late in the bloom progression (Fig. 3). Substrate supply is also thought to be the limiting factor for bacterioplankton during spring bloom conditions in the Ross Sea (Carlson et al. 1998). Perhaps the flux of substrate during the AWS98 bloom was not as low as inventories might indicate; the low levels of DOM were apparently still useful enough to the 


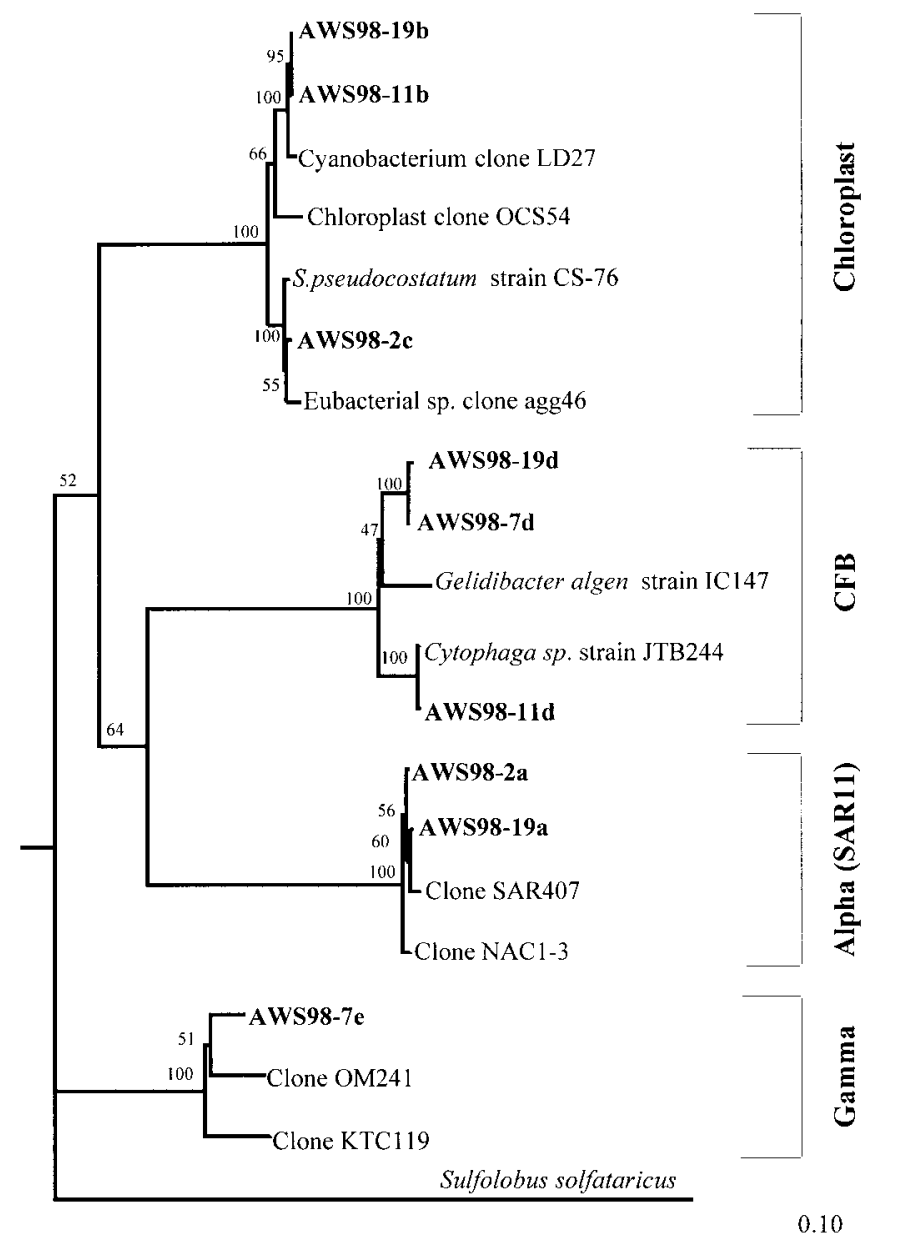

Fig. 7. Dendrogram for AWS98 clones homologous to DGGE bands. The first number following the AWS98 prefix corresponds to the station number where the original sample was taken. The lowercase letter following the station number corresponds to the uppercase letter in Fig. 6 and designates the DGGE band to which the clone sequence was homologous. Numbers at junctions give percentage of bootstrap replicates that support the branching; the scale bar indicates the number of substitutions per $100 \mathrm{bp}$.

bacterial community to cause a significant increase in cell volume and metabolic activity (Fig. 4). This active response may have been facilitated by the use of cold-adapted extracellular enzymes (e.g., Huston et al. 2000) by particle-associated bacteria. Kinetic parameters (Fig. 5) indicate an active community well suited for taking up low levels of labile DOM at low temperature; CTC activities confirm that the active community during peak bloom was particle-associated.

One key finding from these data is the importance of making multiple measures of bacterial activity. In this highly seasonal environment, balanced growth can not be assumed; cell division may not be the first response to new resources. If abundance had been the only bacterial measurement, a lag or substrate threshold (i.e., no response by the bacterial community without a high enough level of DOM) might have been inferred. Only after a suite of other changes, including a shift in community structure, did bacterial abundance in-

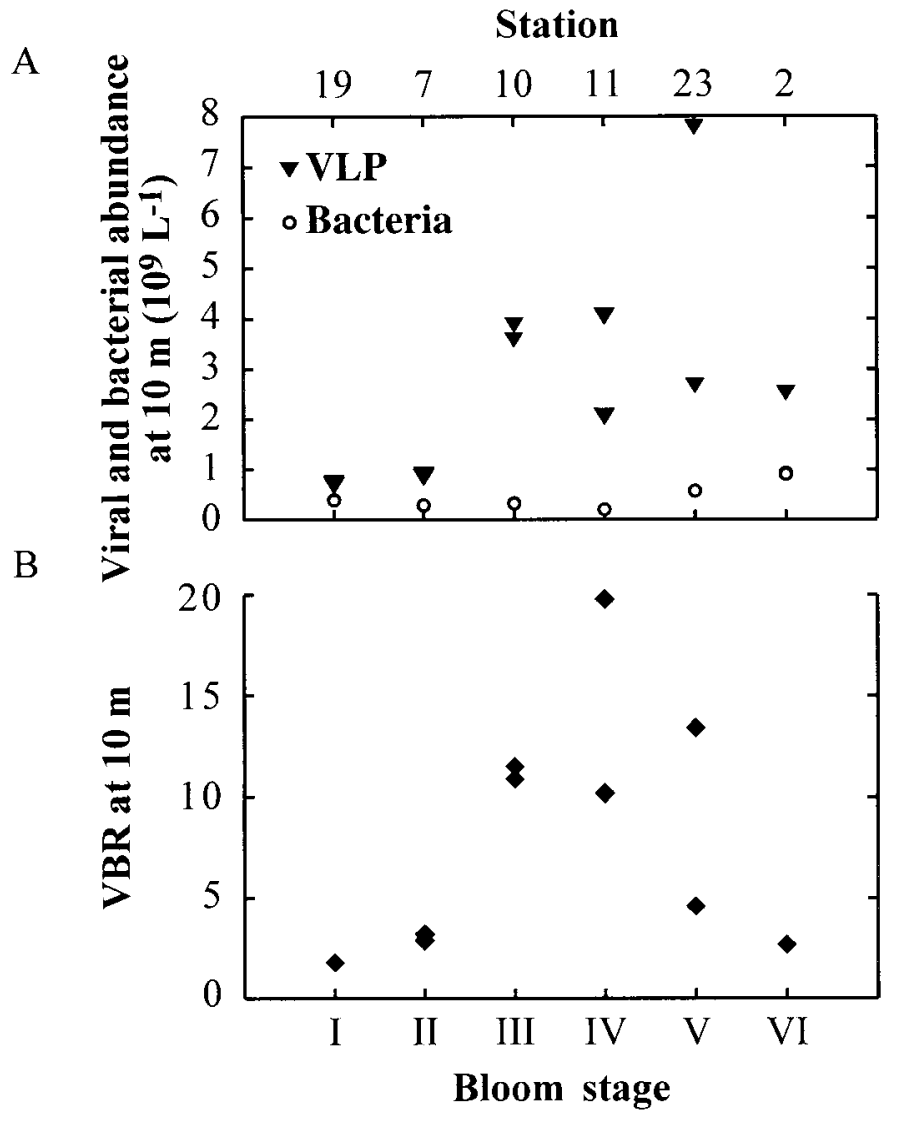

Fig. 8. (A) Virioplankton and bacterial (same as on Fig. 4) abundance $\left(10^{9} \mathrm{~L}^{-1}\right)$ as a function of algal bloom stage; (B) VBR as a function of algal bloom stage. The high variability seen especially at Stages IV and V reflects sample patchiness (duplicate Niskin bottles); analytical variability is much lower.

crease coincident with an increase in DOM. Abundance can be a poor indicator of bacterial activity in polar environments.

Dramatic changes in viral abundance, on the other hand, are so far the only measure of the virioplankton response to this spring bloom. If viral abundance can be used as an indicator of viral activity (see discussion by Wommack and Colwell 2000 and references therein), then the virioplankton must have responded to increasing algal biomass, increasing bacterial activity, or both. VBR can correlate with virioplankton production and bacterioplankton lysis (Wommack and Colwell 2000) and commonly exhibits an inverse relationship with bacterial abundance. This effect was observed at Sta. 11, where VBR increased dramatically and bacterial abundance decreased slightly. VBR values $<1$ are thought to indicate low levels of viral-mediated bacterial mortality, whereas VBR values $>10$ (generally observed when combined viral and bacterial abundance exceeds $10^{12} \mathrm{~L}^{-1}$ ) are conditions favoring bacterial lysis (Wilcox and Fuhrman 1994). That viral abundance did not keep pace with increasing bacterial abundance during Stage VI (Fig. 7) may reflect the reduction in the percentage of active cells, increasing phage resistance and growth by the bacterial community, or that viral infection was more focused on the algae, which 
were likely declining under the low nutrient conditions at Stage VI.

These springtime Arctic bloom data demonstrate that in situ variations in microbial activity and substrate uptake capabilities can be attributed to changes in microbial community structure. Similar to observations of mesocosm blooms (Riemann et al. 2000), an $\alpha$-Proteobacteria strain related to the SAR11 cluster disappeared during the peak of the bloom but reappeared afterward. Strains related to $C y$ tophaga were most prominent during peak algal bloom, coincident with the highest percent of particle-associated CTC + bacteria. Cytophaga species are known for particle association and the degradation of complex macromolecules. They also appear during pronounced increases of cell-specific growth rates and cell-specific enzyme activities among particle-attached bacteria (Riemann et al. 2000), and their specific growth rates were faster than those of the total community in protein-enriched mesocosms (Pinhassi et al. 1999).

Although the bloom stages observed in the Arctic demonstrate features similar to those observed in mesocosm studies (e.g., Pinhassi et al. 1999; van Hannen et al. 1999b; Riemann et al. 2000), whether a temporal sequence of events can truly be inferred from the in situ data remains to be shown. The proposed bloom progression is best supported, however, during the critical shifts between Stages II and IV, where samples were taken sequentially near the same geographic location, within $5 \mathrm{~d}$ of each other. Physical oceanographic data for this part of the Chukchi shelf (Weingartner et al. 1998; Münchow pers. comm.) suggest that the same water mass was sampled at these three stations and that surface currents over the temporal $(<1$ week) and spatial $(<1$ $\mathrm{km})$ scales of interest were probably small.

To model or predict microbial activity, the mechanisms behind microbial community succession must be understood. Although the causes of the observed succession are unknown, likely mechanisms include shifts in type and quantity of available substrate (e.g., Hollibaugh 1994; Murray et al. 1998; van Hannen et al. 1999b), selective viral mortality (e.g., Wommack et al. 1999a,b; Riemann et al. 2000), and selective grazing (e.g., Gonzalez et al. 1993). Since these processes may differ in their specific impacts on community structure and biogeochemical cycling (Fuhrman 1999), distinguishing between them is a major challenge for microbial ecology.

Genetic diversity and substrate limitation can interact directly with viral impacts. Unlike classic "top-down" pressure from bacterivory, viral lysis releases the entire contents of the host cell into the DOM pool in the form of macromolecules, cell organelles, and virus particles, potentially benefiting uninfected microorganisms (Bratbak et al. 1990; Fuhrman 1999; Wilhelm and Suttle 1999). Viruses are also likely to be highly selective in the species or strains they infect and may, therefore, shape the species composition of bacterio- and phytoplankton host communities (Fuhrman and Suttle 1993; Hennes et al. 1995; Wommack et al. 1999b). Blooms of particular host strains may induce microepidemics of certain viruses; fast-growing or numerically abundant host strains can be specifically controlled by viral infection (Wommack et al. 1999a,b). At the same time, uninfected strains would benefit from DOM released by the lysis of infected strains (Noble et al. 1999), driving community succession.

Is the Arctic especially favorable to viruses? Some of the highest recorded VBR values $(\sim 70)$ occurred in sea-ice samples taken during a spring bloom in Resolute, Canada (Maranger et al. 1994). Viral abundance in sea ice increased with increasing chlorophyll concentration, suggesting that viral populations responded to the increase in primary production during the spring bloom. However, vertical profiles of the sea ice and underlying water column revealed that the highest viral abundance also occurred in the region of highest bacterial production. Because the pelagic Arctic experiences a combination of strong seasonality, episodic and significant blooms, potentially specialized hosts, and a high degree of particle-associated microbial activity during blooms that concentrates microbes and increases encounter rates, the potential exists for high levels of virus-mediated mortality within springtime Arctic microbial communities.

The effects of bacterivory on this early season ecosystem remain unknown. Protist samples were collected during the expedition but were damaged and provided no useful data. Bacterivory can cause shifts in bacterial community structure (e.g., Suzuki 1999; van Hannen et al. 1999a), although these changes more likely result from size and morphotype selectivity (e.g., Hahn and Hofle 1999; Jurgens et al. 1999) than from selection of particular bacterial genotypes. If selective bacterivory caused the observed community shift, a targeting of larger cells (Gonzalez 1996 and references therein) or more active cells (Gonzalez et al. 1993) would be expected. Instead, an increase in bacterial cell size was observed over the bloom (Fig. 4), and no major shift in the distribution of morphotypes occurred (Table 1). Also, protist grazing likely produces less DOM than viral mortality, since most bacterial carbon consumed by protists is incorporated, respired, or egested as particulates (e.g., Pelegri et al. 1999). Despite these caveats, the impact of bacterivory on this springtime ecosystem could still be significant and remains to be addressed.

On the basis of these observations of the springtime Arctic, an overwintering population of psychrophilic, oligotrophic bacteria is hypothesized to have responded to the springtime increase in algal biomass during early stages of the bloom. Producing extracellular enzymes to generate an increasing flux of DOM and then using constitutive highaffinity binding proteins to capture any newly available DOM may have accomplished this response. By growing larger and becoming more active, these bacteria became more susceptible to viral infection and mortality. The observed microbial community shift is hypothesized to have been driven first by the shut-down (through viral infection) of this newly active psychrophilic bacterial community and then second by their lysis, increasing the DOM available for the as-yet uninfected, psychrotolerant members of the community that require higher concentrations of substrate. Once the DOM level increased, psychrophilic oligotrophs were outcompeted by psychrotolerant copiotrophs with greater maximum uptake rates. An alternative hypothesis instead focuses viral mortality on the algae, causing a shunt of DOM to the bacteria. In this later case, the changing DOM flux would have driven bacterial community succession. 


\section{Conclusions}

Even at subzero temperatures, pelagic bacteria in this study clearly responded to the springtime algal bloom by increasing cell size, increasing the percentage of active bacteria (to an unprecedented $84 \% \mathrm{CTC}+$ ), and eventually doubling bacterial abundance. During the peak of the algal bloom, a shift in cell-specific substrate uptake kinetics (from high-affinity/low- $V_{\max }$ to low-affinity/high- $V_{\max }$ ) occurred that may have been related to an increased flux of organic matter from either the algal bloom itself or to cell lysis caused by viral production. Shifts in community structure occurred throughout the bloom, including the disappearance of an $\alpha$ Proteobacterium and the increasing importance of Cytophaga during peak algal bloom. We detected changes in cell biovolume, the percentage of active cells, and kinetic parameters before observing a change in bacterial abundance, highlighting the need for multiple measures of bacterial activity during non-steady-state conditions. Questions remain about the mechanisms and predictability of the dramatic shifts in microbial community metabolism and composition and whether these shifts alter the flow of organic matter through the Arctic pelagic ecosystem.

\section{References}

AagaARD, K. 1989. A synthesis of the Arctic Ocean circulation. Rapp. P.-V. Reun. Cons. Int. Explor. Mer 188: 11-22.

Altschul, S. F., W. Gish, W. Miller, E. W. Myers, and D. J. LipMAN. 1990. Basic local alignment search tool. J. Mol. Biol. 215: 403-410.

Azam, F., D. C. Smith, and J. T. Hollibaugh. 1991. The role of the microbial loop in Antarctic pelagic ecosystems. Polar Res. 10: $239-243$.

Bano, N., AND J. T. Hollibaugh. 2000. Diversity and distribution of DNA sequences with affinity to ammonia-oxidizing bacteria of the $\beta$ subdivision of the Class Proteobacteria in the Arctic Ocean. Appl. Environ. Microbiol. 66: 1960-1969.

BILlEN, G. 1990. Delayed development of bacterioplankton with respect to phytoplankton: A clue for understanding their trophic relationships. Arch. Hydrobiol. Beih. Ergebn. Limnol. 114: 415-429.

- AND S. Becquevort. 1991. Phytoplankton-bacteria relationship in the Antarctic marine ecosystem. Polar Res. 10: 245-253.

Bower, C. E., AND T. Holm-Hansen. 1980. A salicylate-hypochlorite method for determining ammonia in seawater. Can. J. Fish. Aquat. Sci. 37: 794-798.

Braman, R. S., and S. A. Hendrix. 1989. Nanogram nitrite and nitrate determination in environmental and biological materials by Vanadium (III) reduction with chemiluminescence detection. Anal. Chem. 61: 2715-2718.

Bratbak, B., M. Heldal, S. Norland, and T. F. Thingstad. 1990. Viruses as partners in spring bloom microbial trophodynamics. Appl. Environ. Microbiol. 56: 1400-1405.

Brosius, J., M. L. Palmer, P. J. Kennedy, and H. F. Noller. 1978. Complete nucleotide sequence of a 16S ribosomal RNA gene from Escherichia coli. Proc. Natl. Acad. Sci. USA 75: 4801-4805.

Carlson, C. A., H. W. Ducklow, D. A. Hansell, and W. O. SMITH, JR. 1998. Organic carbon partitioning during spring phytoplankton blooms in the Ross Sea polynya and the Sargasso Sea. Limnol. Oceanogr. 43: 375-386.
Chen, F., J. R. Lu, B. J. Binder, Y. C. Liu, and R. E. Hodson. 2001. Application of digital image analysis and flow cytometry to enumerate marine viruses stained with SYBR gold. Appl. Environ. Microbiol. 67: 539-545.

Cota, G. F., L. R. Pomeroy, W. G. Harrison, E. P. Jones, F. Peters, W. M. Sheldon, AND T. R. Weingartner. 1996. Nutrients, primary production and microbial heterotrophy in the southeastern Chukchi Sea: Arctic summer nutrient depletion and heterotrophy. Mar. Ecol. Prog. Ser. 135: 247-258.

Dickson, A. G., AND C. Goyet [EDS.]. 1996. Handbook of methods for the analysis of the various parameters of the carbon dioxide system in sea water, v. 2.1. Dept. of Energy.

Ducklow, H. W., H. L. Quimby, M. Church, and A. L. SAnford. 1998. Bacterioplankton response to the Phaeocystis bloom in the Ross Sea Polynya, November 1994-January 1996. EOS 79: 171.

Ferrari, V. C., AND J. T. Hollibaugh. 1999. Distribution of microbial assemblages in the Central Arctic Ocean basin studied by PCR/DGGE: Analysis of a large data set. Hydrobiologia 401: 55-68.

FuHRMAN, J. A. 1999. Marine viruses and their biogeochemical and ecological effects. Nature 399: 541-548.

—, AND C. A. SutTLE. 1993. Viruses in marine planktonic systems. Oceanography 6: 51-63.

GonZALEZ, J. M. 1996. Efficient size-selective bacterivory by phagotrophic nanoflagellates in aquatic ecosystems. Mar. Biol. 126: $785-789$.

— B. F. SHERr, AND E. B. SHERr. 1993. Differential feeding by marine flagellates on growing versus starving, and on motile versus nonmotile bacterial prey. Mar. Ecol. Prog. Ser. 102: 257-267.

Hahn, M. W., ANd M. G. Hofle. 1999. Flagellate predation on a bacterial model community: Interplay of size-selective grazing, specific bacterial cell size, and bacterial community composition. Appl. Environ. Microbiol. 65: 4863-4872.

HARDER, W., AND H. VeldKAMP. 1971. Competition of marine psychrophilic bacteria at low temperatures. Antonie Leeuwenhoek 37: 51-63.

Hennes, K. P., C. A. Suttle, And A. M. Chan. 1995. Fluorescently labeled virus probes show that natural virus populations can control the structure of marine microbial communities. Appl. Environ. Microbiol. 61: 3623-3627.

Hollibaugh, J. T. 1994. Relationship between thymidine metabolism, bacterioplankton community metabolic capabilities and sources of organic matter. Microb. Ecol. 28: 117-131.

Huston, A. L., B. B. Krieger-Brockett, And J. W. Deming. 2000. Remarkably low temperature optima for extracellular enzyme activity from Arctic bacteria and sea ice. Environ. Microbiol. 2: 383-388.

Jurgens, K., J. Pernthaler, S. Schalla, and R. Amann. 1999. Morphological and compositional changes in a planktonic bacterial community in response to enhanced protozoan grazing. Appl. Environ. Microbiol. 65: 1241-1250.

KaneKo, T., R. M. Atlas, AND M. Krichevsky. 1977. Diversity of bacterial populations in the Beaufort Sea. Nature 270: 596599.

- M. I. Krichevsky, And R. M. Atlas. 1979. Numerical taxonomy of bacteria from the Beaufort Sea. J. Gen. Microbiol. 110: $111-125$.

KARL, D. M. 1993. Microbial processes in the Southern Ocean, p. 1-63. In E. I. Friedmann and A. B. Thistle [eds.], Antarctic microbiology. Wiley-Liss.

Knap, A., A. Michaels, A. Close, H. Ducklow, and A. Dickson [EDS.]. 1996. Protocols for the Joint Global Ocean Flux Study (JGOFS) core measurements. JGOFS Report No. 19. Reprint of the IOC Manuals and Guides No. 29, 1994. UNESCO. 
KoRolefF, F. 1983. Determination of nutrients, p. 125-187. In K. Grasshoff, M. Ehrhardt, and K. Kremling [eds.], Methods of seawater analysis, 2nd ed. Verlag Chemie.

LindROTH, P., AND K. MoPPER. 1979. High performance liquid chromatographic determination of subpicomole amounts of amino acids by precolumn fluorescence derivatization with opthaldialdehyde. Anal. Chem. 51: 1667-1674.

LOH, A. N., AND J. E. BAUER. 2000. Distribution, partitioning and fluxes of dissolved and particulate organic $\mathrm{C}, \mathrm{N}$ and $\mathrm{P}$ in the eastern North Pacific and Southern Oceans. Deep-Sea Res. I. 47: 2287-2316.

Maranger, R., D. F. Bird, And S. K. Juniper. 1994. Viral and bacterial dynamics in Arctic sea ice during the spring algal bloom near Resolute, N.W.T., Canada. Mar. Ecol. Prog. Ser. 111: $121-127$.

MoritA, R. Y. 1997. Bacteria in oligotrophic environments. Chapman \& Hall.

Murray, A. E., C. M. Preston, R. Massana, L. T. Taylor, A. Blakis, K. Wu, AND E. F. Delong. 1998. Seasonal and spatial variability of bacterial and archael assemblages in the coastal waters near Anvers Island, Antarctica. Appl. Environ. Microbiol. 64: 2585-2595.

Myers, R. M., S. G. Fischer, L. S. Lerman, and T. Maniatis. 1985. Nearly all single base substitutions in DNA fragments joined to a GC-clamp can be detected by denaturing gradient gel electrophoresis. Nucleic Acids Res. 13: 3131-3145.

Nedwell, D. B., AND M. RutTer. 1994. Influence of temperature on growth rate and competition between two psychrotolerant Antarctic bacteria: Low temperature diminishes affinity for substrate uptake. Appl. Environ. Microbiol. 60: 1984-1992.

Noble, R. T., M. Middleboe, And J. A. Fuhrman. 1999. Effects of viral enrichment on the mortality and growth of heterotrophic bacterioplankton. Aquat. Microb. Ecol. 18: 1-13.

Pelegri, S. P., U. Christaki, J. Dolan, and R. Rassoulzadegan. 1999. Particulate and dissolved organic carbon production by the heterotrophic nanoflagellate Pteridomonas danica Patterson and Fenchel. Microb. Ecol. 37: 276-284.

Pinhassi, J., F. Azam, J. Hempälä, R. A. Long, J. Martinez, U. L. ZweIFEL, AND A. Hagström. 1999. Coupling between bacterioplankton species composition, population dynamics, and organic matter degradation. Aquat. Microb. Ecol. 17: 13-26.

Pomeroy, L. R., AND W. J. Wiebe. 1993. Energy sources for microbial food webs. Mar. Microb. Food Webs 7: 101-118.

Putt, M., D. K. Stoecker, and J. Altstatt. 1991. Bacterivory in McMurdo Sound: 1. Grazing by heterotrophic nanoflagellates. Antarct. J. US 26: 139-140.

Rich, J. H., M. Gosselin, E. Sherr, B. Sherr, AND D. L. KirchMAN. 1997. High bacterial production, uptake and concentration of dissolved organic matter in the Central Arctic Ocean. Deep-Sea Res. II 44: 1645-1663.

Riemann, L., G. F. Steward, F. Azam. 2000. Dynamics of bacterial community composition and activity during a mesocosm diatom bloom. Appl. Environ. Microbiol. 66: 578-587.

Rivkin, R. B., M. R. ANDERSON, AND C. LAJZERowicz. 1996. Microbial processes in cold oceans. 1. Relationship between temperature and bacterial growth rate. Aquat. Microb. Ecol. 10: 243-254.

SAmbrotto, R. N., H. J. Niebauer, J. J. Goering, and R. L. IVerSON. 1986. Relationships among vertical mixing, nitrate uptake, and phytoplankton growth during the spring bloom in the southeast Bering Sea middle shelf. Continental Shelf Res. 5: $161-198$

Sherr, B. F., P. DEL Giorgio, E. B. Sherr. 1999. Estimating abun- dance and single-cell characteristics of respiring bacteria via the redox dye CTC. Aquat. Microb. Ecol. 18: 117-131.

SHerr, E. B., B. F. SHERr, AND L. FesSEnden. 1997. Heterotrophic protists in the Central Arctic Ocean. Deep-Sea Res. II 44: $1665-1682$.

SHIAH, F. K., AND H. W. DuCKLOW. 1994. Temperature regulation of heterotrophic bacterioplankton abundance, production, and specific growth rate in Chesapeake Bay. Limnol. Oceanogr. 39: $1243-1258$.

Steward, G. F., D. C. Smith, and F. Azam. 1996. Abundance and production of bacteria and viruses in the Bering and Chukchi Seas. Mar. Ecol. Prog. Ser. 131: 287-300.

Strickland, J. D., AND T. R. PARSONS. 1972. A practical handbook of seawater analysis. Bull. Fish. Res. Board Can. 167: 310.

SuZUKI, M. T. 1999. Effect of protistan bacterivory on coastal bacterioplankton diversity. Aquat. Micro. Ecol. 20: 261-272.

Turley, C. M., And D. J. Hughes. 1992. Effects of storage on direct estimates of bacterial numbers of preserved seawater samples. Deep-Sea Res. 39: 375-394.

van Hannen, E. J., M. Veninga, J. Bloem, H. J. Gons, and H. J. LAANBroEK. 1999a. Genetic changes in the bacterial community structure associated with protistan grazers. Archiv fur Hydrobiol. 145: 25-38.

, G. Zwart, M. P. van Agterveld, H. J. Gons, J. Ebert, AND H. J. LAANBRoEK. 1999b. Changes in bacterial and eukaryotic community structure after mass lysis of filamentous cyanobacteria associated with viruses. Appl. Environ. Microbiol. 65: 795-801.

Weingartner, T., D. J. Cavalieri, K. Aagaard, and Y. Sasaki. 1998. Circulation, dense water formation, and outflow on the northeast Chukchi shelf. J. Geophys. Res. 103: 7647-7661.

Wheeler, P. A., J. M. Watkins, and R. L. Hansing. 1997. Nutrients, organic carbon and organic nitrogen in the upper water column of the Arctic Ocean: Implications for the sources of dissolved organic carbon. Deep-Sea Res. II 44: 1571-1592.

Wiebe, W. J., W. M. SHeldon, ANd L. R. Pomeroy. 1992. Bacterial growth in the cold: Evidence for an enhanced substrate requirement. Appl. Environ. Microbiol. 58: 359-364.

-1 , AND 1993. Evidence for an enhanced substrate requirement by marine mesophilic bacterial isolates at minimal growth temperatures. Microb. Ecol. 25: 151-159.

Wilcox, R. M., AND J. A. Fuhrman. 1994. Bacterial viruses in coastal seawater: Lytic rather than lysogenic production. Mar. Ecol. Prog. Ser. 114: 35-45.

Wilhelm, S. W., And C. A. Suttle. 1999. Viruses and nutrient cycles in the sea. Bioscience 49: 781-788.

Wommack, K. E., And R. R. Colwell. 2000. Virioplankton: Viruses in aquatic environments. Microb. Molec. Biol. Rev. 64: 69-114.

, J. Ravel, R. T. Hill, J. Chun, And R. R. Colwell. 1999a. Population dynamics of Chesapeake Bay virioplankton: total community analysis using pulsed field gel electrophoresis. Appl. Environ. Microbiol. 65: 231-240.

—,,-- AND R. R. Colwell. 1999b. Hybridization analysis of Chesapeake Bay virioplankton. Appl. Environ. Microbiol. 65: 241-250.

Yager, P. L., AND J. W. Deming. 1999. Pelagic microbial activity in an arctic polynya: Testing for temperature and substrate interactions using a kinetic approach. Limnol. Oceanogr. 44: $1882-1893$.

Received: 2 October 2000 Amended: 20 December 2000 Accepted: 11 January 2001 